\title{
Ammonium alum in alum-treated wooden artefacts: discovery, origins and consequences
}

\author{
Caitlin M. A. McQueen ${ }^{1 *} \mathbb{D}$, Jeannette J. Łucejko², Ingrid M. T. Flåte ${ }^{1}$, Francesca Modugno ${ }^{2}$ and Susan Braovac ${ }^{1}$
}

\begin{abstract}
Alum-treatment was extensively applied to archaeological wood from the Oseberg collection in the early 1900s, and was a common conservation method at the time involving impregnating objects with hot concentrated solutions of potassium alum $\left(\mathrm{KAl}\left(\mathrm{SO}_{4}\right)_{2} \cdot 12 \mathrm{H}_{2} \mathrm{O}\right)$. This now obsolete consolidation method has led to dramatic long-term consequences, heavily affecting the state of preservation of the historical wooden artefacts, and dedicated chemical characterisation campaigns have been undertaken to better understand the degradation processes and aid development of re-treatment strategies. Analyses with Fourier transform infrared spectroscopy (FTIR), elemental microanalysis, and ion chromatography $(\mathrm{IC})$ was performed, suggesting the presence of ammonium alum $\left(\mathrm{NH}_{4} \mathrm{Al}\left(\mathrm{SO}_{4}\right)_{2} \cdot 12 \mathrm{H}_{2} \mathrm{O}\right)$ in many alum-treated wood samples, though no record exists of use of ammonium compounds during treatment of the artefacts. C/N rations of 1.70-68.8 in wood samples, and ammonium alum contents between 8 and $84 \%$ of the alum component and 23-168 mmol/100 $\mathrm{g}$ of total sample suggested that objects were actually treated with various mixes of potassium and ammonium alum. The two alums have similar properties, and in model studies of their behaviour under the conditions of alum-treatment appeared to form similarly acidic solutions, thus the different alum mixtures probably did not significantly influence object treatment. Nor have we observed other indications of unusual degradation pathways related specifically to the presence of ammonium alum. Nonetheless, investigations into potential re-treatment of the archaeological objects must be adjusted accordingly.
\end{abstract}

Keywords: Oseberg find, Alum-treated archaeological wood, Ammonium alum, Potassium alum, FTIR, Microanalysis, $\mathrm{IC}, \mathrm{pH}$, Conservation

\section{Introduction}

After excavation in the early 1900 s, many of the waterlogged wooden artefacts from the Viking age Oseberg collection in Norway were alum-treated, which was a widely used conservation method up until the 1950s, especially in Scandinavia [1-3]. The treatment, as it was used on the most degraded wood from the Oseberg finds, involved soaking the waterlogged fragments in hot $\left(90^{\circ} \mathrm{C}\right)$ concentrated solutions of alum $\left(\mathrm{KAl}\left(\mathrm{SO}_{4}\right)_{2} \cdot 12 \mathrm{H}_{2} \mathrm{O}\right)$ for an average of $24 \mathrm{~h}$, in order to prevent shrinkage during drying [4]. Though the alum-treatment method is now obsolete, its consequences are still being faced today. Alum-treated objects from the Oseberg collection

\footnotetext{
*Correspondence: caitlin.mcqueen@khm.uio.no

${ }^{1}$ Department of Collection Management, Museum of Cultural History,

University of Oslo, Postboks 6762, St. Olavs plass, 0130 Oslo, Norway
}

Full list of author information is available at the end of the article demonstrate extreme deterioration, the full extent of which has only been realised in the past decade. The release of sulfuric acid due to decomposition of alum during treatment is thought be a key factor in the ongoing deterioration of these objects $[5,6]$. However, the fact that this method had not been in use for decades meant that, when the issues with the Oseberg artefacts became apparent, there was limited understanding of the chemical nature of alum-treated wood in general. Improving this is important for developing future preservation strategies, and as such the Oseberg collection is an important case study with potentially wide-ranging implications. Alum-treated wood may be present in many collections, and our group has had the opportunity to develop new material knowledge about alum-treated archaeological wood using an extensive range of analytical techniques to characterise organic and inorganic components of wood samples from alum-treated Oseberg artefacts [7-10]. 
During these investigations, ammonium alum $\left(\mathrm{NH}_{4} \mathrm{Al}\left(\mathrm{SO}_{4}\right)_{2} \cdot 12 \mathrm{H}_{2} \mathrm{O}\right)$ was clearly identified by X-ray diffraction (XRD), FTIR and was supported by elemental analysis [10]. As available information mentions only treatment with potassium alum [11], and no mention of ammonium alum in alum-treated objects had been reported elsewhere to our knowledge, this was somewhat surprising. Alum-treated wood from the Oseberg collection was the wood that was most bacterially degraded on excavation [12], and since nitrogen-fixing bacteria have been associated with wood decay [13-15], it was considered that ammonia or ammonium compounds could have accumulated to some extent in the wood, and reacted with alum when treated. Another ammonium source could in fact be the alum treatment. Few records of the original alum treatment of the Oseberg artefacts exist today, but texts from the nineteenth and early twentieth century mention that alum was often commercially sold as a mixture of the ammonium and potassium versions [16, 17], either deliberately as they had similar uses, or because the two materials were indistinguishable due to similar physical properties (e.g. melting point, solubility, density) $[18,19]$. The two salts were also difficult to separate once mixed [20].

Since ammonium alum and potassium alum are isomorphous [19] and have many similar properties, it was easy to initially overlook the unanticipated presence of ammonium alum in many other samples. Although we have performed a variety of inorganic analyses [7-9], the difference between the two alums is not immediately clear from their XRD patterns or Raman spectra in complex samples, and elemental analyses we performed in these studies focussed on heavier elements than the nitrogen in ammonium.

In order to work out how widespread ammonium alum is in the collection, its likely source and potential consequences, we undertook a more detailed investigation involving a larger range of objects, FTIR both in attenuated total reflection (ATR) and at microscopic level ( $\mu$ FTIR), nitrogen quantification, ammonium quantification, and model studies of the chemistry of alumtreatment solutions. We describe the results herein and consider their implications in terms of object condition and re-treatment.

\section{Materials and methods Samples}

Samples of alum-treated wood from 11 different Oseberg objects, treated with alum ca. 1905-1912, were analysed, as described in Table 1.

Potassium alum and potassium bisulfate (puriss p.a. $>99 \%)$ were purchased from Sigma-Aldrich. Ammonium alum (purum p.a.>99\%) was purchased from Honeywell.

\section{Alum solutions}

Alums of the following composition were used to reproduce the conditions and reactions undergone by the salts during the conservation treatment: pure $\mathrm{NH}_{4}$-alum, pure K-alum and mixtures of the two in 80:20, 50:50, $20: 80 \mathrm{wt} \%$ ratios.

Table 1 Description of alum-treated wood samples from the Oseberg collection. Wood type given where identified (the objects were too degraded to identify the genus)

\begin{tabular}{|c|c|c|}
\hline Sample prefix & Description & Wood type \\
\hline 185 & $\begin{array}{l}\text { Samples from fragments from object 185, a loom. Fragments do not contain linseed oil or varnish, and have been } \\
\text { sampled from the alum-rich layer. The fragments labelled 185-1 to 6, which originally fit together, are in increasing } \\
\text { state of visual deterioration with increasing suffix number }\end{array}$ & Diffuse porous \\
\hline 229 & $\begin{array}{l}\text { Samples from fragments from object 229, a simple sled, without linseed oil or varnish. The fragments } 5,1 \mathrm{~B}, 1 \mathrm{C}, 1 \mathrm{D} \text { had } \\
\text { distinct alum-rich and alum-poor areas, and were sampled from the "alum rich" (AR) part (close to the surface) }\end{array}$ & Diffuse porous \\
\hline 203 & Samples from fragments from object group 203, pointed sticks for tents or horse tether & - \\
\hline 206 & Samples from fragments of object group 206, from a stretcher & - \\
\hline 207 & $\begin{array}{l}\text { Sample from fragment from object 207, a large baking trough, that were not used in its reconstruction. Linseed oil } \\
\text { coated. Previously cut up for analysis at different depths, and powdery residue was reserved for further study }\end{array}$ & Diffuse porous \\
\hline 210 & $\begin{array}{l}\text { Samples from object 210, which consists of fragments of an unreconstructed large barrel or vat, wooden parts of } \\
\text { which have been treated with alum and thoroughly impregnated with linseed oil }\end{array}$ & Ring porous \\
\hline 250 & $\begin{array}{l}\text { Sample from fragment of object 250, a reconstructed carved board coated with linseed oil and varnish. Fragment } 2 \\
\text { was from a broken off piece, sampled from inside to avoid contamination with linseed oil }\end{array}$ & Diffuse porous \\
\hline 275 & Samples from fragments of object 275, a chest & - \\
\hline 279 & Assorted fragments from different objects: coffin, nail, casket, plate, loom & - \\
\hline 296 & Samples of fragments from unknown object 296 & - \\
\hline 410 & Samples from fragments of object 410 , a bed & - \\
\hline
\end{tabular}


$40 \mathrm{~g}$ alum was combined with $20 \mathrm{~g}$ distilled water and heated in a water bath at $90-95{ }^{\circ} \mathrm{C}$ with shaking, such that the salts dissolved. The various mixtures were heated for 29, 96 and 189/209 h. Any precipitate that had formed was separated from the supernatant via hot filtration (to prevent recrystallisation of alum), dried and weighed. The $\mathrm{pH}$ of a sample of the cooled solution after the 96 and $189 / 209 \mathrm{~h}$ heating times was measured with a $\mathrm{pH}$ strip.

In repeat experiments with $\mathrm{NH}_{4}$-alum, $\mathrm{K}$-alum and the 50:50 wt\% mixture (three replicates each), the $\mathrm{pH}$ was measured during heating using a Mettler Toledo SevenExcellence $\mathrm{pH}$ Meter equipped with an InLab Micro ProISM pH electrode, which has an integrated temperature probe for temperature compensation $\left(0-100^{\circ} \mathrm{C}\right)$.

\section{FTIR}

FTIR spectra in ATR mode were recorded on a Thermo Scientific Nicolet iS50 spectrometer equipped with a diamond crystal and DTGS detector. Spectra of samples and alum references were recorded with 32 scans at $4 \mathrm{~cm}^{-1}$ resolution, within the range $4000-400 \mathrm{~cm}^{-1}$.

Micro-infrared spectroscopy ( $\mu$ FTIR) was performed both with conventional IR radiation (using the above instrument), and synchrotron radiation (SR). SR- $\mu$ FTIR, which gave improved spatial resolution, was carried out at the IRIS beamline at the BESSY II synchrotron facility, Helmholtz-Zentrum Berlin Germany, using a Nicolet Nexus 870 spectrometer. Samples were compressed in a diamond cell and spectra obtained using a Nicolet Continuum FTIR microscope. Spectra were recorded in transmittance mode with a spectral resolution of $4 \mathrm{~cm}^{-1}$, within the range $4000-650 \mathrm{~cm}^{-1}$ and $4000-800 \mathrm{~cm}^{-1}$ for conventional and synchrotron radiation, respectively. Each spectrum in the maps was recorded with 128 scans and spot analyses were recorded with 256 scans. Reference spectra were obtained from OMNIC software libraries.

Estimates of ammonium alum content were performed on aqueous extracts of the wood samples, obtained by suspending a weighed amount of ground wood powder in water for 10-30 min, centrifuging and separating the supernatant three successive times or until sulfate test strips measured $<200 \mathrm{mg} / \mathrm{L}$. The dried residues from the extracts were weighed, ground into fine powders, and three replicate FTIR spectra recorded in ATR mode for each residue. The height of the sulfate band $\left(\mathrm{h}_{\mathrm{SO} 4}\right)$ around $1080 \mathrm{~cm}^{-1}$ was normalised to 1 and the area of the ammonium band at $1436 \mathrm{~cm}^{-1}\left(\mathrm{~A}_{\mathrm{NH} 4}\right)$ was measured using OMNIC software, and the values from the three replicates averaged to give the $\mathrm{A}_{\mathrm{NH} 4} /$ $\mathrm{h}_{\mathrm{SO} 4}$ ratio. A linear calibration curve $\left(r^{2}=0.997\right)$ was obtained from a plot of ammonium alum concentration versus the $\mathrm{A}_{\mathrm{NH} 4} / \mathrm{h}_{\mathrm{SO} 4}$ in five standard mixtures of pure ammonium alum and potassium alum ranging from 0-100 mol\% ammonium alum (as a percentage of total alum content). Linear regression was used to calculate the ammonium alum concentrations in sample extracts from this calibration curve, along with the standard error of the prediction.

\section{Microanalysis}

Microanalysis was performed by the Laboratory for Elemental Analysis, Department of Chemistry, University of Bergen. $\mathrm{C}, \mathrm{H}$ and $\mathrm{N}$ were quantified in samples (dried in vacuo) using an Elementar Vario EL III instrument.

\section{Ion chromatography}

Analyses were performed with a Dionex ICS-1000 instrument, equipped with a suppressed conductivity detector. For cation analyses, an IonPac ${ }^{\circledR}$ CS12 $4 \times 250 \mathrm{~mm}$ Analytical Column, which is specifically conceived for the analysis of alkali metals, alkaline earth metals and ammonium, and an IonPac ${ }^{\circledR}$ CG12 $4 \times 50 \mathrm{~mm}$ Guard Column were used. The eluent was $20 \mathrm{mM}$ methane sulfonic acid and the suppressor was a Cation Self-generating Suppressor $300 \times 4 \mathrm{~mm}\left(\mathrm{CSRS}^{\circledR} 300\right)$. For anion analyses, an IonPac ${ }^{\circledR}$ AS $4 \mathrm{~A} 4 \times 250 \mathrm{~mm}$ Analytical Column and an IonPac ${ }^{\circledR}$ AG $4 \mathrm{~A} 4 \times 50 \mathrm{~mm}$ Guard Column were used. The eluent was an aqueous solution of $\mathrm{Na}_{2} \mathrm{CO}_{3}(1.8 \mathrm{mM})$ and $\mathrm{NaHCO}_{3}(1.7 \mathrm{mM})$ and the suppressor was an Anion Self-generating Suppressor $300 \times 4 \mathrm{~mm}\left(\right.$ ASRS $\left.^{\circledR} 300\right)$.

ICS-1000 operation is remote controlled by Chromeleon Software (version $6.7 \mathrm{SP} 1$ ) that also provides data acquisition and data processing functions.

For the chromatographic analyses, a given amount of water was added to a weighed amount of the sample. The solution was then stirred for $2 \mathrm{~h}$, decanted for half an hour and then filtered with hydrophilic PTFE filters (pore size $0.45 \mu \mathrm{m}$ ). Results were normalized referring them to $100 \mathrm{mg}$ of powder.

\section{X-ray diffraction}

X-ray diffraction (XRD) analysis was carried out using a PANalytical diffractometer Empyrean Series 2 with radiation $\mathrm{CuK} \alpha=1.54 \AA$, operating at $45 \mathrm{kV}, 40 \mathrm{~mA}$, equipped with a PIXcel ${ }^{1 \mathrm{D}}$ (Medipix3) detector. HighScore Plus suite was used for data analyses [21]. Crystalline phases were identified using the ICDD-2016 database. Measurements were performed using a reflection-transmission spinner stage and zero background sample holder, with $2 \theta$ range $8-70^{\circ}$, step size $0.03^{\circ}$, rotation time $16 \mathrm{~s}$, time per step $798 \mathrm{~s}$. 


\section{Results and discussion}

Identification of ammonium in alum-treated wood samples The main feature we used here to clearly distinguish ammonium from potassium alum was a distinctive band in the FTIR spectrum around $1430 \mathrm{~cm}^{-1}$. This is attributable to a $v_{4}$ deformation band for the $\mathrm{NH}_{4}{ }^{+}$ion, the frequency of which is $1400 \mathrm{~cm}^{-1}$ for the free ion and is shifted in crystals due to hydrogen bonding [22, 23]. These bands were observed in the FTIR spectra of many of the wood samples from the collection, with varying intensities. Such evidence of ammonium alum was first noticed in $\mu$ FTIR maps, from which fairly pure spectra of small alum particles could be obtained. For certain samples, several map spectra matched tschermigite, the mineral form of ammonium alum, such as in fragment 229-1C-AR (Fig. 1). The distinctive band around $1430 \mathrm{~cm}^{-1}$ recurred in microscope spectra from many of the other fragments from object 229 , as well as objects 185, 210 and 250. However, despite this recurrent evidence of ammonium compounds, they were not apparent in XRD patterns or Raman spectra, though as mentioned above, it is difficult to distinguish ammonium alum from potassium alum in complex samples using the these techniques. The only clear indication of another ammonium compound was in some FTIR spectra from spot analysis of small particles in 185-6, which were consistent with ammonium sulfate (Fig. 2).
Having identified these particles, we also studied previously acquired ATR-FTIR spectra for such $\mathrm{NH}_{4}$ bands. Such bands were often not clear in ATR-FTIR spectra from the same objects, due to the presence of lignocellulosic bands from wood also in the same spectral region. However, in several cases where alum dominated the spectrum, the $\mathrm{NH}_{4}$ band could be clearly seen. This was the case in the outer region of fragment 207 [10], as well as in certain samples from objects 203, 206, 275 and 279, as shown in Fig. 3. In ATR mode the $\mathrm{NH}_{4}$ deformation band is shifted slightly to $1436 \mathrm{~cm}^{-1}$, and when relatively strong is distinct from lignocellulosic peaks around 1456 and $1423 \mathrm{~cm}^{-1}$ observed for wood from the same samples after rinsing away the alum.

\section{Quantification of nitrogen and ammonium}

Having identified 1440/1436 $\mathrm{cm}^{-1}$ FTIR bands associated with the ammonium ion for samples from several separate objects, we wished to confirm that these were indeed due ammonium species, and to get an idea of the quantity of ammonium in order to determine its likely origin and its potential impact on the objects. Microanalysis was therefore performed on a number of wood samples to determine the nitrogen abundance relative to carbon. The results are shown in Table 2 as $\mathrm{C} / \mathrm{N}$ ratios, which range between 1.70 and 68.8. Although nitrogen levels in bacterially degraded wood have been found to be relatively high, $\mathrm{C} / \mathrm{N}$ ratios as low as 110 in archaeological

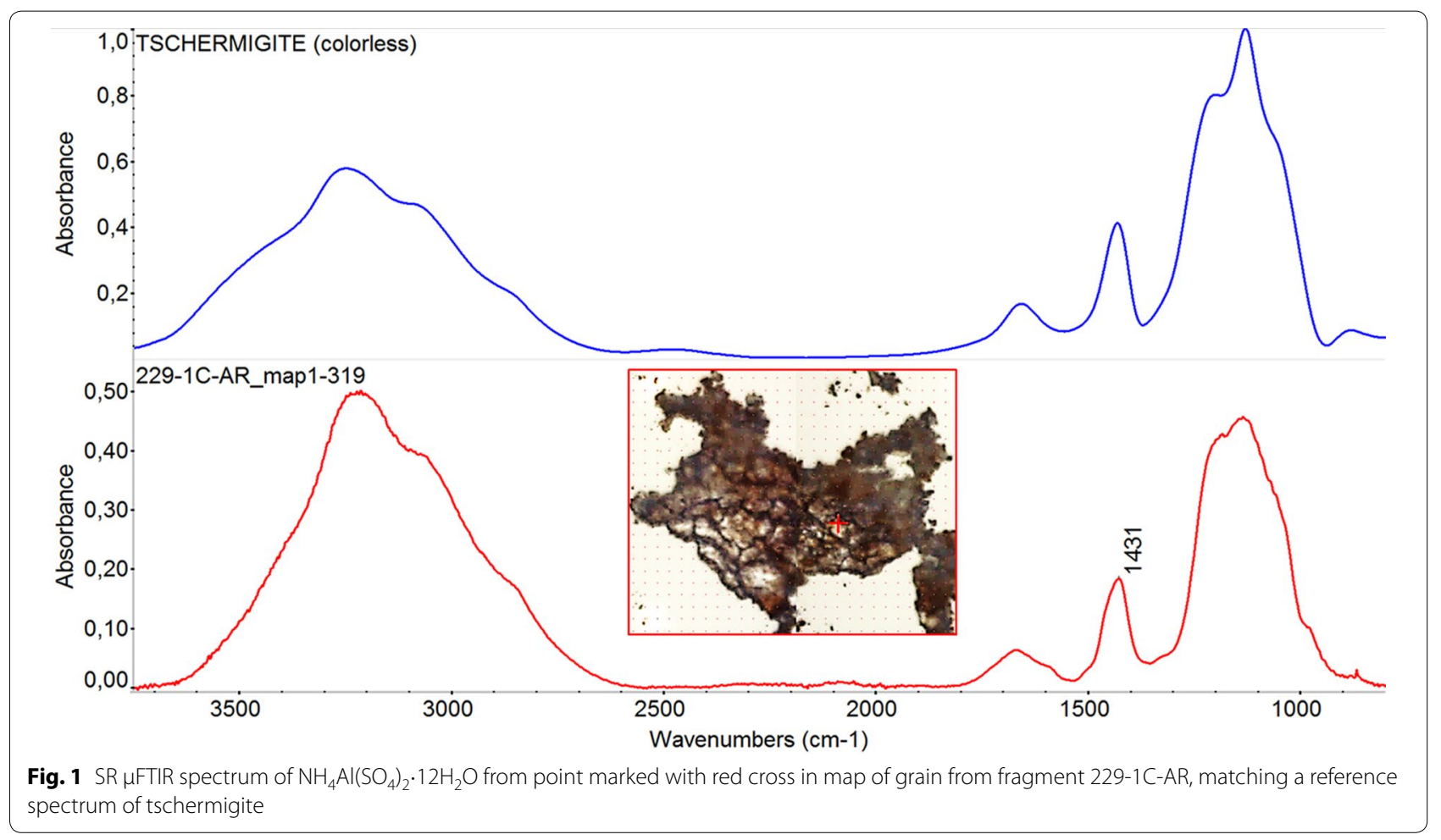



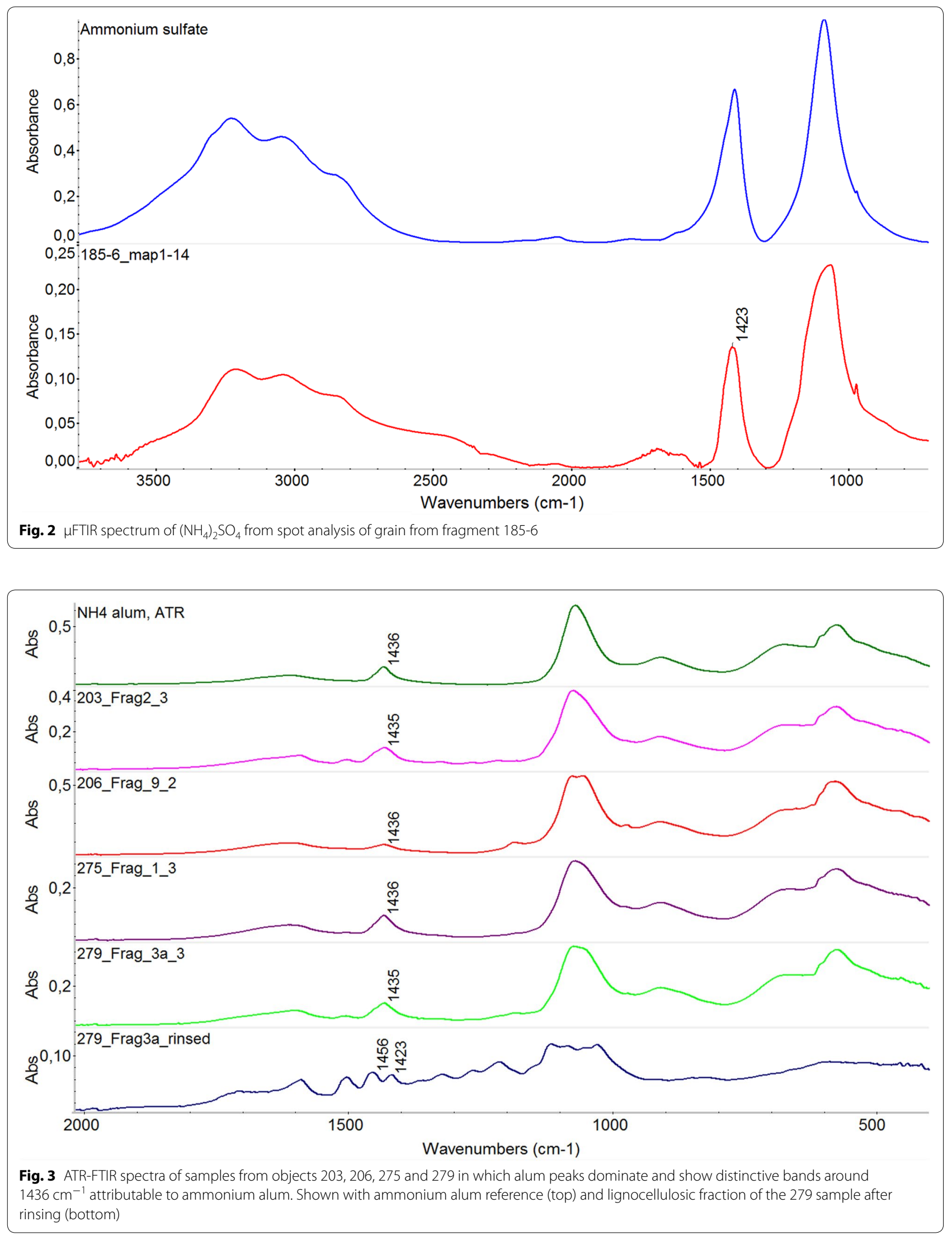
Table 2 Nitrogen, ammonium and ammonium alum contents of several alum-treated Oseberg wood samples, determined by elemental microanalysis, ATR-FTIR quantification and IC

\begin{tabular}{|c|c|c|c|c|}
\hline \multirow[t]{2}{*}{ Sample } & \multirow{2}{*}{$\begin{array}{l}\text { Microanalysis } \\
\mathrm{C} / \mathrm{N}\end{array}$} & \multicolumn{2}{|l|}{ ATR-FTIR } & \multirow{2}{*}{$\begin{array}{l}\mathrm{IC} \\
\mathrm{NH}_{4} \\
(\mathrm{mmol} / 100 \mathrm{~g})\end{array}$} \\
\hline & & $\mathrm{NH}_{4}$-alum conc. of alum (mol\%) & $\mathrm{NH}_{4}$ estimate $(\mathrm{mmol} / 100 \mathrm{~g})$ & \\
\hline 185-F1 & 4.75 & & & \\
\hline $250-2$ & 68.8 & & & \\
\hline 279-3a & 1.70 & & & \\
\hline $410-5$ & 2.22 & & & \\
\hline 229-1B-AR & 7.09 & $17 \pm 2$ & $33 \pm 4$ & 31.8 \\
\hline 229-1C-AR & 6.29 & $18 \pm 2$ & $35 \pm 4$ & 35.4 \\
\hline 229-1D-AR & 11.1 & $18 \pm 2$ & $32 \pm 4$ & 36.0 \\
\hline 229-5-AR & 11.3 & $17 \pm 2$ & $31 \pm 4$ & 23.7 \\
\hline $185-1$ & 10.1 & $14 \pm 2$ & $29^{\mathrm{a}} \pm 4$ & $25.1^{\mathrm{a}}$ \\
\hline $185-2$ & 8.56 & $13 \pm 2$ & $27^{\mathrm{a}} \pm 4$ & $25.1^{\mathrm{a}}$ \\
\hline $185-3$ & 9.87 & $17 \pm 2$ & $36^{\mathrm{a}} \pm 4$ & $15.1^{\mathrm{a}}$ \\
\hline $185-4$ & 8.18 & $11 \pm 2$ & $24^{a} \pm 4$ & $38.6^{\mathrm{a}}$ \\
\hline $185-6$ & 3.71 & $13 \pm 2$ & $27 \pm 4$ & \\
\hline 207-powder & & $84 \pm 2$ & $168 \pm 4$ & \\
\hline $296-1$ & & $8 \pm 2$ & $16 \pm 4$ & \\
\hline
\end{tabular}

Values marked with ${ }^{\text {a }}$ denote quantities per $100 \mathrm{~g}$ of aqueous extract, rather than $100 \mathrm{~g}$ of total wood sample. The mass of the dried extracts accounted for $85-98 \%$ of the mass of the total samples

wood [24] are still considerably higher than the alumtreated Oseberg samples, indicating unnaturally high levels of nitrogen and pointing toward alum-treatment as a nitrogen source. Table 2 also shows results of IC analysis of aqueous extracts of the 229 samples, which confirm levels of ammonium around $30 \mathrm{mmol} / 100 \mathrm{~g}$ of sample.

Supposing on the basis of these results that the alum in the objects is indeed a mixture of ammonium and potassium versions, we sought to determine the proportions of each type of alum in the samples, using ATR-FTIR as a convenient tool. Since lignocellulosic FTIR bands from the wood fraction occur in a similar region to the ammonium and sulfate bands of interest, the alum was extracted in water and analysis performed on the dried extracts. Ammonium alum content in aqueous extracts of the wood samples was estimated based on the relative intensities of the ammonium and sulfate bands. Extracts that could be analysed effectively by this method were those that contained almost no FTIR bands that could not be attributed to either potassium or ammonium alum (i.e. contained essentially undetectable amounts of other compounds). Notably, in all analysed samples, some content of ammonium alum was determined, with concentrations ranging between about $8-84 \mathrm{~mol} \%$ of total alum content (with standard error of the prediction, $s_{x}$, around $2 \mathrm{~mol} \%$ for all samples). We used these results to estimate the amount of ammonium in the whole sample, based on the mass of the extracted fraction, assuming the extract consisted entirely of potassium or ammonium alum. This gave values ranging from 23 to $168 \mathrm{mmol} / 100 \mathrm{~g}$ of the total sample, generally lower than $\mathrm{K}$ and $\mathrm{Al}$ values previously found by inductively coupled plasma-optical emission spectroscopy $[7,8]$, but with the same orders of magnitude, consistent with the ammonium alum being a significant but minor component of the alum mixture in most cases. We compared these values to values obtained by IC analysis of the samples from objects 229 and 185 . These were generally in good, though not exact, agreement, confirming that the FTIR method was a reasonable means of estimating ammonium content. Note that 185 fragments were sampled separately for FTIR and IC analysis, therefore the larger differences in results of the $185-3$ and 185-4 samples may be due to inhomogeneity within the fragment.

There is not a large variation in ammonium content within samples that came from the same objects (229 samples and 185 samples), which would be consistent with ammonium having been introduced in a mixed alum treatment bath. Significant variation is, however, observed between objects, suggesting that these were treated with differently proportioned alum mixtures.

\section{Ammonium and potassium alum solutions in the lab}

Before these findings, we had understood that the original solutions used to treat objects were of pure potassium alum. In hot potassium alum solutions, hydrolysis 
of aqueous $\mathrm{Al}$ species is known to lead to the precipitation of alunite $\left(\mathrm{KAl}_{3}\left(\mathrm{SO}_{4}\right)_{2}(\mathrm{OH})_{6}\right)$, accompanied by the release of sulfuric acid, as shown in Eq. 1, and resulting in a drop in $\mathrm{pH}(\mathrm{pH} 2-2.5$ after $24 \mathrm{~h}$ heating vs $\mathrm{pH} 3.5-4$ in unheated solutions) $[5,12]$.

$$
\begin{aligned}
& 3 \mathrm{KAl}\left(\mathrm{SO}_{4}\right)_{2}+12 \mathrm{H}_{2} \mathrm{O} \rightarrow \mathrm{KAl}_{3}\left(\mathrm{SO}_{4}\right)_{2}(\mathrm{OH})_{6} \\
& +2 \mathrm{~K}^{+}+4 \mathrm{SO}_{4}^{2-}+6 \mathrm{H}_{3} \mathrm{O}^{+}
\end{aligned}
$$

Having established the presence of $\mathrm{NH}_{4}$-alum, and that it was likely introduced into objects during alum treatment, we considered how this would change the chemistry of our prototypical alum solutions. We therefore investigated the behaviour of $\mathrm{NH}_{4}$-alum, $\mathrm{K}$-alum, and mixtures thereof under conditions used during alum treatment, namely in concentrated solutions heated to $90{ }^{\circ} \mathrm{C}$. Although wooden objects from Oseberg were treated for an average of $24 \mathrm{~h}$, we considered that the solutions themselves could have been heated for longer to perform several successive treatments, and therefore also evaluated alum solutions after heating for 4 days (96 h) and over a week (189/209 h).

The mass of precipitate formed for different heating times is shown in Fig. 4. We observe that the amount of precipitate obtained from the $100 \% \mathrm{NH}_{4}$-alum solution is much lower than for the mixtures containing $\mathrm{K}$-alum. $\mathrm{X}$-ray diffraction of the precipitates from the $100 \%$ K-alum solution and the 20:80 $\mathrm{K}: \mathrm{NH}_{4}$-alum solution identified mainly alunite (Fig. 5). Very minor additional peaks in the latter pattern could be remnant alum, but were too small to identify. FTIR spectroscopy confirmed that the $\mathrm{NH}_{4}{ }^{+}$content in the precipitates was very low, judging by little to no absorption around $1440 \mathrm{~cm}^{-1}$. In the case of $100 \% \mathrm{NH}_{4}$-alum, the amount of precipitate was too little to separate from the filter paper. It seems, therefore, that while alunite formed readily under these conditions in the presence of potassium, the ammonium equivalent, ammonioalunite $\left(\mathrm{NH}_{4} \mathrm{Al}_{3}\left(\mathrm{SO}_{4}\right)_{2}(\mathrm{OH})_{6}\right)$, did not. Indeed, in a mineralogical context, ammonioalunite occurs rarely compared to its potassium counterpart, under specific conditions including high acidity $(\mathrm{pH}<2)$ and very low $\mathrm{K}$ concentrations [25], and a text on the manufacture of aluminium sulfates mentions that the ammonium analogue of alunite is obtained from mixture of ammonium sulfate, aluminium sulfate and water kept at $190^{\circ} \mathrm{C}[20]$.

We also observe in Fig. 4 that the amounts of alunitecontaining precipitate for all the mixtures were of similar orders to that from the $100 \% \mathrm{~K}$-alum solution. There is not a clear trend with the proportion of K-alum, and even less so when the mass of precipitate was converted to a $\%$ yield, so alunite formation did not seem to depend on $\mathrm{K}$ concentration, as long as $\mathrm{K}$ was available. Even in the 20:80 K: $\mathrm{NH}_{4}$-alum solution, the precipitate formed after $209 \mathrm{~h}$ would only have consumed $9.2 \%$ of the available potassium.

The mass of precipitate formed was very small relative to the mass of alum dissolved, less than $2.5 \mathrm{wt} \%$. The amount of precipitate also increased with heating time for the mixtures containing K-alum. Since most reactions slow down as the reactants are consumed, we would expect this to be the case here. However, since we have

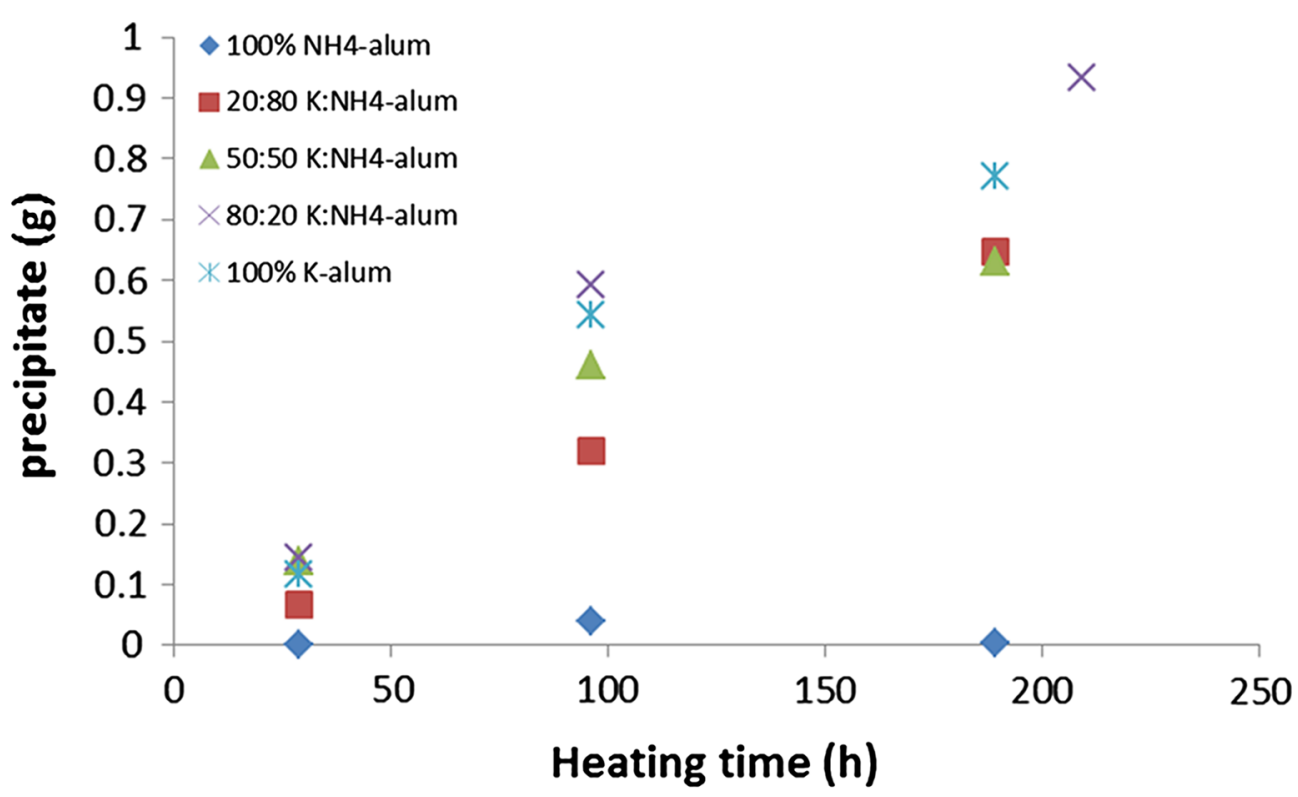

Fig. 4 Mass of precipitate produced by heating identical amounts of alum solutions ( $40 \mathrm{~g}$ alum with $20 \mathrm{~g}$ water) over time 


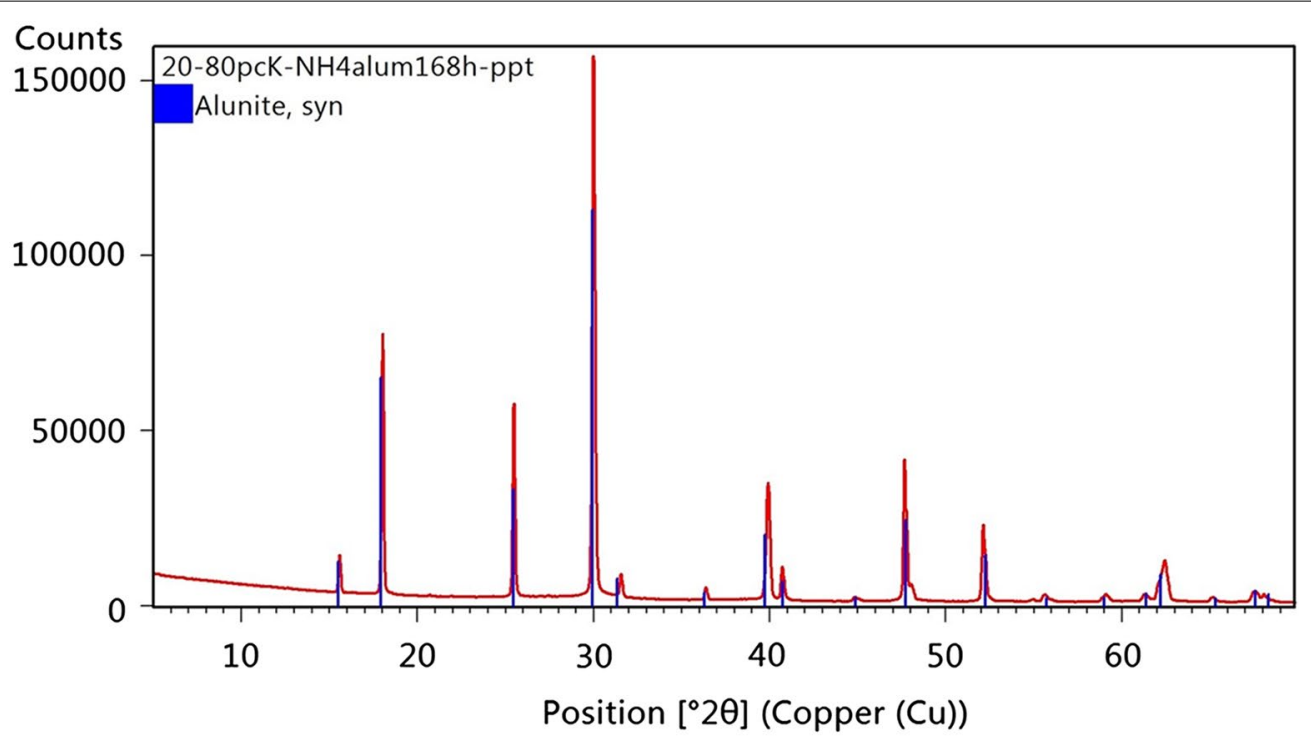

Fig. 5 XRD pattern of precipitate from 80:20 K: $\mathrm{NH}_{4}$-alum mixture with alunite reference

only a few points in time and the potential for experimental error during filtration, we cannot really draw conclusions about the reaction rate from these results.

Recalling the variation in ammonium alum proportions in different Oseberg objects, we considered if $\mathrm{NH}_{4}$ enrichment in the heating phase could account for the different $\mathrm{K}: \mathrm{NH}_{4}$ ratios in the original treatment baths. Since K-containing alunite precipitates readily but the $\mathrm{NH}_{4}$-containing equivalent does not, and the amount that precipitates increases with time, the $\mathrm{K}: \mathrm{NH}_{4}$ ratio in solution would decrease over time. However, assuming a hypothetical solution with $80 \mathrm{~mol} \mathrm{~K}$-alum and $20 \mathrm{~mol}$ $\mathrm{NH}_{4}$-alum (i.e. an 80:20 K: $\mathrm{NH}_{4}$ ratio), then to reach a 20:80 K: $\mathrm{NH}_{4}$ ratio in the solution, $75 \mathrm{~mol}$ of the $\mathrm{K}$ content would have to be precipitated to give $75 \mathrm{~mol}$ of alunite, but only 33 mol could be formed before all the $\mathrm{Al}$ was consumed. To even decrease the $\mathrm{K}_{\mathrm{NH}} \mathrm{NH}_{4}$-alum ratio, from say 86:14 to 82:18, precipitation of 22 equivalents of $\mathrm{K}$ and consumption of $66 \%$ of the $\mathrm{Al}$ in solution would be required. If the fastest observed alunite precipitation rate of $0.932 \mathrm{~g}$ (7.9\% yield) in $209 \mathrm{~h}$ did not decrease with time, it would still take at least 72 days of continuous heating to produce a $66 \%$ yield of alunite. The alumtreatment of the Oseberg artefacts was performed over the course of years [12], so the same impregnation solutions could possibly have been used for this much time. However, such prolonged heating of solutions and extensive reaction of K-alum would surely have had other consequences (e.g. drying out of solutions, precipitation of other salts and overall reduction in alum concentration, extreme acidity), so it seems doubtful that the baths would have been used for so long without being topped up or refreshed. The differences in $\mathrm{K} \mathrm{NH}_{4}$-alum ratios observed in the Oseberg objects would be more plausibly explained by use of different batches of alum salt with varying $\mathrm{K}: \mathrm{NH}_{4}$ ratios.

Regarding the acidity of the heated solutions, the same $\mathrm{pH}$ was measured (with $\mathrm{pH}$ strips) for the corresponding cooled solutions after 4 days and one week, with values of $\mathrm{pH}=1$ for pure $\mathrm{K}$-alum and the alum mixtures and $\mathrm{pH}=3$ for pure $\mathrm{NH}_{4}$-alum. However, repeat experiments with $\mathrm{K}$-alum, $\mathrm{NH}_{4}$-alum and a 50:50 wt\% mixture showed a similar drop in $\mathrm{pH}$ (measured by $\mathrm{pH}$ meter) in the hot solutions over time, as shown in Fig. 6a. The initial observed $\mathrm{pH}$ between 3-3.5 was measured at room temperature for the salt-water mixtures before heating. The $\mathrm{pH}$ then decreased rapidly for all samples as they were heated to form a homogeneous solution and for the next two hours, after which the $\mathrm{pH}$ change slows considerably. However, as $\mathrm{pH}$ is a logarithmic scale, Fig. $6 \mathrm{~b}$, showing the $\mathrm{pH}$ values converted to hydronium ion concentrations, is a better representation of the rate of acid formation. In this representation, the rate of hydronium formation does appear to decrease over time, but much less rapidly than the $\mathrm{pH}$ graph would suggest. The fact that the pure $\mathrm{NH}_{4}$-alum samples shows similar trends to the other samples, despite minimal precipitate formation and the relatively high $\mathrm{pH}$ of the cooled solutions, suggests that the same acid-forming reactions are occurring in all hot alum solutions, but that the precipitation of alunite in the solutions containing potassium prevents the reverse reaction on cooling. 


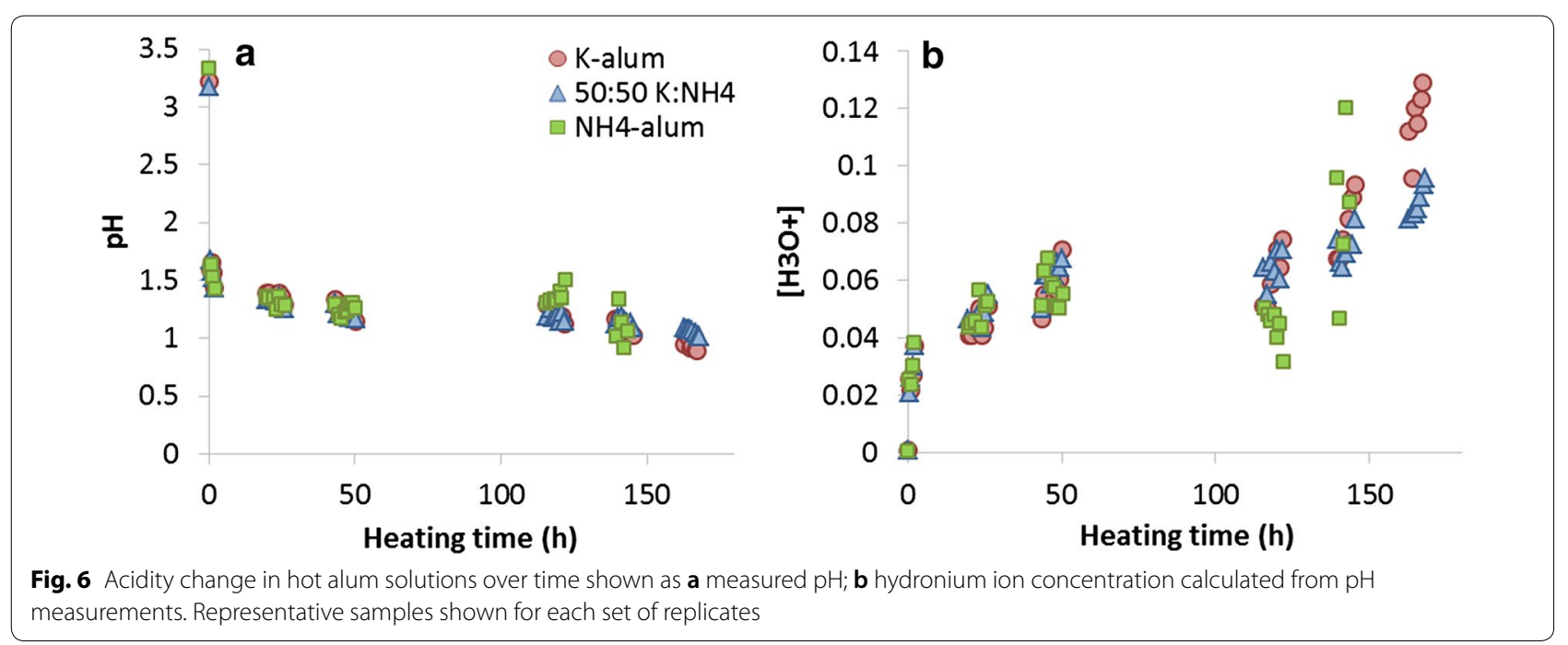

\section{Effects on object condition and re-treatment}

The results of these investigations suggest that ammonium alum was introduced into Oseberg artefacts during alum-treatment with ammonium and potassium alum mixtures. The variation in ammonium alum proportions in different objects therefore suggests different $\mathrm{K}: \mathrm{NH}_{4}$ ratios in the original treatment baths, most likely due to different batches of alum salt being used. We have also observed that hot alum solutions are comparably acidic for both types of alum and mixtures thereof, and therefore different alum salt mixtures should have influenced objects similarly during alum-treatment.

In terms of the stability of the alum crystals, we have recently shown that potassium and ammonium alum respond similarly to relative humidity $(\mathrm{RH})$ and temperature fluctuations, and seem to be stable at temperatures up to $60{ }^{\circ} \mathrm{C}$ at $50 \% \mathrm{RH}$, and at $\mathrm{RH} 15-75 \%$ at $25{ }^{\circ} \mathrm{C}$ [26]. However, an acidic by-product of the reaction shown in Eq. 1, $\mathrm{KHSO}_{4}$, which has been identified in alum-treated wood samples from objects 185 and 229 [8], is very unstable under the same conditions. Potassium alum or its degradation products also seem to react with iron corrosion products in composite artefacts to form sulfate compounds containing iron and potassium [9]. Ammonium versions of these alteration products have not been clearly identified in any of the Oseberg samples so far. This might be because the ammonium equivalents do not form as readily under the same conditions, as with alunite. Most of the salts we have identified occur naturally as minerals, and often do not have known ammonium equivalents in mineral databases (e.g. $\mathrm{KHSO}_{4}$, which occurs naturally as mercallite). However $\left(\mathrm{NH}_{4}\right)_{2} \mathrm{SO}_{4}$ does occur naturally (mascagnite) and was identified in one sample, as shown above in Fig. 2, in a $\mu$ FTIR map of a small grain, but not in non-microscopic analysis of the same sample. As ammonium alum was the minor alum component in most samples analysed, other ammonium salts could also be present in amounts below limits of detection. Nonetheless, we can state that, so far, we have not found evidence of reactions of ammonium alum to any significant extent in the alum-treated wood samples.

In terms of the wood condition, we have observed considerable variability in our studies of the collection. This could be due to many factors that we have limited or no records of, such as original condition upon recovery and treatment conditions (e.g. type of alum used, solution heating time and extent of alum breakdown, concentration, immersion time), and whether additional materials such as linseed oil were used in treatment. It is therefore difficult to attribute different conditions of two separate objects to any specific factor. For example, we note that the analytical pyrolysis results of samples from object 207 [10], in which the alum content was largely ammonium alum, reflect a less degraded wood component than the results of samples from objects 185 and 229 [7, 8], in which the alum component is largely potassium alum. However, object 207 had also been treated with linseed oil, whereas 185 and 229 had not, and the study suggested a possible preservative effect of linseed oil in this fragment based on differences observed in different regions of the fragment. Furthermore, $\mathrm{pH}$ strips indicated that the fragment from $207(\mathrm{pH} \sim 2.5)$ was less acidic than the samples from $185(\mathrm{pH} \sim 1)$. Within the same object, given that the $\mathrm{K}: \mathrm{NH}_{4}$ ratios appear fairly constant, the variability in ammonium content would be related to the variability in total alum content. In our previous studies, we have noted that contents of most elements and ions 
related to alum tend to correlate strongly with measures of wood degradation [8], and thus the effects of specific ions or elements is not easily differentiated from variation in total alum content.

In any case, we might expect differences in ammonium and potassium alum reactivity to new materials being introduced in object re-treatment. Our group is developing a de-acidification method involving application of $\mathrm{Ca}(\mathrm{OH})_{2}$ nanoparticles to alum-treated wood [27], during which ammonium could potentially be volatilised as ammonia gas. To gain further insight, investigations are currently being undertaken into the specific products resulting from reactions of the nanoparticles with potassium and ammonium salts present in the wood.

\section{Conclusions}

We have discovered the widespread presence of ammonium alum in many alum-treated objects from the Oseberg collection. Microanalysis, IC and FTIR revealed unnaturally high nitrogen and ammonium contents in a range of samples, and indicated that ammonium alum was mixed with potassium alum in the salts used to treat the objects. The results suggested a wide range of ammonium alum contents ranging from 8 to $84 \%$ of the total alum content.

The two alums have similar properties, including response to $\mathrm{RH}$ and temperature fluctuation, and appear to form comparably acidic solutions when heated. In Oseberg wood samples, we have not observed evidence of significant reactions of ammonium alum. Its effect on wood degradation is so far inconclusive and likely to remain so due to difficulties separating ammonium content from other factors influencing wood condition. However, as a result of this work, investigations into the reactivity of both alums toward de-acidification agents are underway and should provide information about whether volatilisation of ammonia and other reactivity differences should be a concern during re-treatment.

\footnotetext{
Abbreviations

FTIR: Fourier transform infrared spectroscopy; $\mu F T I R$ : micro-infrared spectroscopy; SR: synchrotron radiation; IC: ion chromatography; XRD: X-ray diffraction.
}

\begin{abstract}
Acknowledgements
We wish to thank Helmholtz-Zentrum Berlin for the allocation of synchrotron beamtime for $\mu$ FTIR measurements. The assistance of Dr Ulrich Schade and Dr Ljiljana Puskar at the IRIS beamline is gratefully acknowledged. We also thank Dr Barbara Sacchi from Institute for the Conservation and Valorisation of Cultural Heritage (ICVBC), National Research Council (CNR), Florence for performing IC analysis, Inger Johanne Fjellanger from the University of Bergen for performing microanalysis, and Dr Diego Tamburini for assistance with acquiring synchrotron spectra and fruitful discussions regarding the origins of ammonium.
\end{abstract}

\section{Authors' contributions}

CM and SB collected samples from the artefacts and performed FTIR analysis. SB designed and performed the alum solution experiments. IF performed the second round of alum solution experiments. CM performed XRD analysis. Jt organised IC analysis and interpreted data on wood condition. CM collected and interpreted the data overall, and wrote the manuscript, which was critically reviewed and edited by SB, $ヒ$ and FM. All authors read and approved the final manuscript.

\section{Funding}

This work was carried out as part of the Saving Oseberg project, funded by the Norwegian Ministry of Education and Research and the University of Oslo.

\section{Availability of data and materials}

The datasets used and/or analysed during the current study are available from the corresponding author on reasonable request.

\section{Competing interests}

The authors declare that they have no competing interests.

\section{Author details}

${ }^{1}$ Department of Collection Management, Museum of Cultural History, University of Oslo, Postboks 6762, St. Olavs plass, 0130 Oslo, Norway. ${ }^{2}$ Department of Chemistry and Industrial Chemistry, University of Pisa, via Moruzzi 13, 56124 Pisa, Italy.

Received: 2 August 2019 Revised: 23 September 2019 Accepted: 26 September 2019

Published online: 04 October 2019

\section{References}

1. Brorson Christensen B. The conservation of waterlogged wood in the National Museum of Denmark. Copenhagen: National Museum of Denmark; 1970

2. Häggström C, Lindahl K, Sahlstedt M, Sandström T, Wikstad E. Alumtreated archaeological wood: characterization and re-conservation. Stockholm: Swedish National Heritage Board; 2013.

3. Eaton JW. The preservation of wood by the alum process. Florida Anthropol. 1962;15(4):115-7.

4. Brøgger AW, Shetelig H, Falk H. Osebergfundet. Oslo: Distribuert ved Universitetets Oldsaksamling; 1917.

5. Braovac S, Kutzke $H$. The presence of sulfuric acid in alum-conserved wood - Origin and consequences. J Cult Herit. 2012;13(3):S203-S208208.

6. Braovac S, McQueen CMA, Sahlstedt M, Kutzke H, Łucejko JJ, Klokkernes T. Navigating conservation strategies: linking material research on alumtreated wood from the Oseberg collection to conservation decisions. Herit Sci. 2018;6(1):77

7. Braovac S, Tamburini D, Łucejko JJ, McQueen C, Kutzke H, Colombini MP. Chemical analyses of extremely degraded wood using analytical pyrolysis and inductively coupled plasma atomic emission spectroscopy. Microchem J. 2016:124:368-79.

8. McQueen CMA, Tamburini D, Łucejko JJ, Braovac S, Gambineri F, Modugno F, et al. New insights into the degradation processes and influence of the conservation treatment in alum-treated wood from the Oseberg collection. Microchem J. 2017;132:119-29.

9. McQueen CMA, Tamburini D, Braovac S. Identification of inorganic compounds in composite alum-treated wooden artefacts from the Oseberg collection. Sci Rep. 2018;8(1):2901.

10. Łucejko JJ, La Nasa J, McQueen CMA, Braovac S, Colombini MP, Modugno F. Protective effect of linseed oil varnish on archaeological wood treated with alum. Microchem J. 2018;139:50-61.

11. Rosenqvist AM. The stabilizing of wood found in the viking ship of Oseberg: part I. Stud Conserv. 1959;4(1):13-22.

12. Braovac S. Alum-treated wood - Material characterisation: a case study of the Oseberg finds [Doctoral thesis]. Copenhagen: The Royal Danish Academy of Fine Arts-Schools of Architecture, Design and Conservation; 2015.

13. Jurgensen MF, Tonn JR, Graham RT, Harvey AE, Geier-Hayes K. Nitrogen fixation in forest soils of the inland northwest. For Sci. 1984;30(4):1038-44.

14. Larsen MJ, Jurgensen MF, Harvey AE. N2 fixation associated with wood decayed by some common fungi in western Montana. Can J For Res. 1978;8(3):341-5. 
15. Hendrickson OQ. Abundance and activity of N2-fixing bacteria in decaying wood. Can J For Res. 1991;21(9):1299-304.

16. Acidulous sulphate of alumina and potash, or alum. In: Maclaren C, editor. Encyclopaedia Britannica. 6th ed, vol. 5. Edinburgh: Archibald Constable; 1823. p. 604-5.

17. Thorpe E. A dictionary of applied chemistry. London: Longmans, Green and Co.; 1918. p. 118-122.

18. Mellor JW. Aluminium sulphate and the alums. Modern inorganic chemistry. London: Longmans, Green; 1912. p. 450-451.

19. Weast RC, Selby SM. CRC Handbook of chemistry and physics. 48th ed. Cleveland, Ohio: The Chemical Rubber Co.; 1967.

20. Geschwind $L$. The manufacture of alum and the sulphates and other salts of alumina and iron. London: Fb\&c Limited; 2015. (Original ed. 1901)

21. Degen T, Sadki M, Bron E, König U, Nénert G. The HighScore suite. Powder Diffr. 2014;29(S2):S13-8.

22. Chourabi B, Fripiat JJ. Determination of tetrahedral substitutions and interlayer surface heterogeneity from vibrational spectra of ammonium in smectites. Clays Clay Miner. 1981;29(4):260-8.
23. Nakamoto K. Infrared and Raman spectra of inorganic and coordination compounds : Pt. A : theory and applications in inorganic chemistry. 6 th ed. New York: Wiley; 2009.

24. Gelbrich J. Bacterial wood degradation : a study of chemical changes in wood and growth conditions of bacteria. Göttingen: Sierke Verlag; 2009.

25. Altaner SP, Fitzpatrick JJ, Krohn MD, Bethke PM, Hayba DO, Goss JA, et al. Ammonium in alunites. Am Mineral. 1988;73(1-2):145-52.

26. McQueen CMA, Steindal CC, Narygina O, Braovac S. Temperature- and humidity-induced changes in alum-treated wood: a qualitative $X$-ray diffraction study. Herit Sci. 2018;6(1):66.

27. Andriulo F, Braovac S, Kutzke H, Giorgi R, Baglioni P. Nanotechnologies for the restoration of alum-treated archaeological wood. Appl Phys A. 2016;122(4):322.

\section{Publisher's Note}

Springer Nature remains neutral with regard to jurisdictional claims in published maps and institutional affiliations.

\section{Submit your manuscript to a SpringerOpen ${ }^{\circ}$ journal and benefit from:}

- Convenient online submission

- Rigorous peer review

- Open access: articles freely available online

- High visibility within the field

- Retaining the copyright to your article

Submit your next manuscript at springeropen.com 